\title{
The Analysis of the Effect of Transformational Leadership and Organizational Culture on Job Satisfaction and Performance
}

\author{
Romaldus Fredimus Lebi ${ }^{1}$, Rina Anindita ${ }^{2}$ \\ A Student of Master of Management of Esa Unggul University Jakarta, Indonesia ${ }^{1}$ \\ A Lecturer of Faculty of Economics and Business \\ Master of Management Study Program of Esa Unggul University Jakarta, Indonesia ${ }^{2}$
}

\begin{abstract}
One of the determining factors of the success of a company is employee performance. Every organization or company will try to be effective, so that the programs implemented can realize the company's goals and visions. The business model implemented is by improving employee performance. The important aspects considered having some effect on performance improvement are transformational leadership, organizational culture, and job satisfaction. This study aimed to find out the effect of transformational leadership and organizational culture on job satisfaction, to find out the effect of transformational leadership and organizational culture on performance, and to find out the effect of job satisfaction on performance. The object of the study was the teachers at several Catholic schools in West Jakarta with a total of 205 respondents. This research used quantitative method with a Likert scale to measure the results research. The research design used was causality design to determine the relationship between two or more variables. The hypotheses used SEM (Structural Equation Modeling) as the analytical technique using Lisrel program. The results showed that transformational leadership and organizational culture have a positive and significant effect on teachers' job satisfaction, transformational leadership has a positive and significant effect on teacher performance, organizational culture does not have any effect on teacher performance, and job satisfaction has a positive effect on teacher performance. This study also found that there was an effect of transformational leadership and organizational culture on teacher performance mediated by job satisfaction.
\end{abstract}

Keywords: Transformational Leadership, Organizational Culture, Job Satisfaction, Performance

\section{INTRODUCTION}

Human resources is the most important asset in a company to realize its visions and goals (Schuler and Jackson, 1997; Armstrong, 2006; Rowley and Jackson, 2012; Ruyatnasih, 2013). In the era of global competition, companies need reliable, competent, and innovative human resources to win the competition. One of the determining factors or parameters is high employee performance. However, there is a need of certain strategy as an effort to improve employee performance. The strategy is an integrated and comprehensive reference framework that directs choices that determine the form and direction of organizational activities towards achieving the goals (Simamora, 1997). In the opinion of the researcher, an effective strategy in order to improve the performance and goals of the company and to create added value for a company is the implementation of transformational leadership, organizational culture, and job satisfaction appropriately in a company. The good transformational leadership, strong organizational culture, and high job satisfaction can improve the performance of teachers. It is the effect of transformational leadership and organizational culture on job satisfaction and performance that encourages the researcher to make further elaboration and analyze it in this study.

The following are some of the previous studies that are related to the research that will be carried out, including Wright, et al (2000). The study concluded that job satisfaction has an effect on employee performance. Lund (2003), in his research, found that organizational culture has a positive effect on job satisfaction. The objects studied were employees in the marketing field in US companies. Nemanich and Keller (2007) concluded that transformational leadership can improve employee performance. Hussami (2008), in his research, concluded that transformational leadership has positively effect on job satisfaction.

Hamidifar (2009), in his research, explored that among the existing leadership styles, transformational leadership has positive effect on job satisfaction, as the employees have higher satisfaction than in other leadership styles. Riaz, et al. (2010) conducted a study on private companies in the capital city of Pakistan. The results the hypothesis test in this study showed that transformational and transactional leadership styles have a positive and significant effect on job satisfaction. 


\title{
International Advanced Research Journal in Science, Engineering and Technology
}

\author{
Vol. 5, Issue 10, October 2018
}

Cumming, et al. (2010) stated that transformational leadership has a positive effect on job satisfaction. Wang, et al. (2011) proved that transformational leadership has a positive effect on employee performance. Voon, et al. (2011) concluded that transformational leadership has a positive relationship with job satisfaction. Bushara, et al. (2011) showed that transformational leadership has a positive effect on job satisfaction.

Another study was also carried out by Paracha, et al. (2012). This study was conducted in private schools in Pakistan. The results showed that transformational and transactional leadership styles have a positive effect on job satisfaction and employee performance. Nahas, et al. (2012) proved that organizational culture has a positive effect on job satisfaction. This research was conducted at the largest company in Greece.

Another study conducted by Jacobs, et al. (2012) at a surgical hospital in the UK. The results concluded that organizational culture has a positive effect on organizational performance. A study conducted by Uddin, et al. (2013) concluded that organizational culture has a positive effect on employee performance. Shahzad, et al. (2013) concluded that organizational culture has a positive effect on employee performance. Meanwhile, Khan, et al. (2013), who conducted research in Pakistan with a total of 200 respondents consisting of doctors, nurses, administrative staff, and officers working in autonomous medical institutions in Punjab-Pakistan, showed that job satisfaction has a significant effect on employee performance. Another study was carried out by Davoodalmousavi (2013). The results of the study showed that organizational culture has a positive and significant effect on job satisfaction. The object studied was the employees who worked in biotechnology companies in Iran.

Funmilola, et al. (2013), in his research, concluded that salary, promotion, supervision, work, and working conditions has some effect on job satisfaction and employee performance. In the study conducted by Ali, et al. (2013), it was concluded that there is a strong relationship between transformational leadership and job satisfaction. Habib, et al. (2014) stated that organizational culture has a positive effect on job satisfaction. This research was conducted on employees working in several companies in the Multan-Punjab, Pakistan. Abouraia, et al. (2017) suggested that transformational leadership has a positive effect on job satisfaction. The objects studied were bank employees in Jeddah, Saudi Arabia.

In this study, the researcher wanted to develop the research conducted by Funmilola, et al. (2013) on the effect of job satisfaction variable on performance. The influencing factors of job satisfaction are salary, supervision, work, and working conditions. Meanwhile, in this study, the researcher wanted to analyze that job satisfaction is resulted from other variables, namely transformational leadership and organizational culture. The good transformational leadership and strong organizational culture can improve job satisfaction. Moreover, the object of the research consisted of several private schools that have the similar characteristics of organizational culture.

The researcher also carried out the development of research conducted by Paracha, et al. (2012). It was found that transactional leadership has greater effect on employee performance than transformational leadership. In addition, transactional leadership does not result in job satisfaction. This is because the employees are pursued by company targets or goals. The employees fear of punishment. All employees conduct activities in order to get bonuses and promotions. Meanwhile, transformational leadership has an effect on job satisfaction. Job satisfaction mediates the effect of transformational leadership on employee performance but not significantly. This research was conducted in Pakistan in a private education institutions with a very autocratic, bureaucratic, and high power distance cultural context. The data were analyzed using multiple regression method.

In this study, researcher assumed that employee or teacher performance depends heavily on the leadership style adopted by an organization. Leadership style plays an important role in improving the performance of teachers or employees. In addition, this research was conducted in Indonesia which has different culture from Pakistan. The data were analyzed using SEM. On this basis, the researcher tried to analyze the effect of transformational leadership, organizational culture, and job satisfaction on teacher performance with the basic assumption that teacher performance can improve when get the effect of strong transformational leadership, strong organizational culture, and high teacher job satisfaction.

\section{LITERATURE REVIEW}

\section{Transformational Leadership}

Transformational leadership is still often similarized with charisma. Bass (1985) argues that transformational leadership is different from charisma. Charisma is a mandatory component in transformational leadership. A leader can be charismatic but not necessarily transformational. The essence of transformational leadership is to inspire followers' commitment to goals, enhance social identification, and develop followers' skills and collective success (Yukl, 2006). Transformational leaders emphasize followers' intrinsic motivation and personal development. Transformational leaders can encourage followers' commitment to the organization and inspire them to reach higher performance than the expected (Ali, et al. 2013). Transformational leadership is the ability to inspire, motivate, and stimulate people intellectually (Avolio, et al. 2004 in Ali, et al. 2013). Kennedy and Anderson (2005) in Ali, et al. (2013) further define transformational leadership as direction through individual consideration, intellectual stimulation, inspirational motivation, and influence in the ideal direction. 


\title{
International Advanced Research Journal in Science, Engineering and Technology
}

\author{
Vol. 5, Issue 10, October 2018
}

Transformational leaders basically change the values, goals, and aspirations of their followers who adopt the values espoused by their leaders and ultimately show consistent performance in accordance with the values they uphold and do not expect any rewards (Ali, et al. 2013). Transformational leadership encourages autonomy and job challenges that are important for the job satisfaction of the followers. Avolio, Bass, and Jung (1997) identify four dimensions of transformational leadership. The four dimensions are idealized influence, inspirational motivation, intellectual stimulation and individualized consideration. Idealized influence dimension refers to leaders who focus on the formation and articulation of the visions and directs goals and motivates the followers to work beyond their personal interests. In this dimension, the leaders act as role models who are highly admired, respected, and trusted by their followers. Inspirational Motivation dimension refers to the way the leaders motivate and inspire their followers to commit to the visions of the organization. Leaders with inspirational motivation drive team spirit toward the desired achievement. Intellectual stimulation dimension deals with the role of the leaders in stimulating innovation and creativity to their followers by asking assumptions and approaches to the old situation into new ways. They always encourage their followers to try new approaches or methods in solving the old problems. Individualized consideration refers to the leaders who pay special attention to the needs of each individual of the followers in order to excel and grow by acting as a coach or mentor.

\section{Organizational Culture}

Robbins and Judge (2016) suggested that organizational culture is a system of meanings held by members that distinguishes an organization from other organizations. Siagian (1995), organizational culture is a mutual agreement (commitment) about the shared values in the life of the organization and binds everyone in the concerned organization. Another definition, according to Kreitner and Kinicki (2005), organizational culture is a form of assumption that is possessed, accepted implicitly by the group and determine how the group perceives, thinks, and reacts to a diverse environment. Lund (2003) in Abdul Hakim (2014) and Maslowski (2001) define organizational culture as philosophy, ideology, values, assumptions, beliefs, expectations, attitudes, and norms in the organization.

According to Schein (1999), organizational culture is a pattern of shared assumptions as learning to overcome external problems and internal integration, taught to new members as the right way to understand, think, and perceive the problem. According to Creemers and Reynolds (1993) in Soetopo (2010), organizational culture is a pattern of shared beliefs and expectations by members of the organization. According to Gibson, et al. (2005) in Soetopo (2010), organizational culture is an organizational personality that influences how individuals act in organizations.

Ogbonna and Harris (2000) in Sobirin (2007) interpret organizational culture as beliefs, values, meanings, and assumptions that are collectively shared by a social group to help reinforcing the way they interact and in responding to the environment . Robbins (2006) suggests that organizational culture is often portrayed in the sense in which it is shared. The belief patterns, symbols, rituals, and myths that develop over time and serve as unifiers that unite the organization. Culture can be defined as various interactions of habitual characteristics that affect groups of people in their environment. From some of the definitions above it can be concluded that organizational culture is a pattern or system in the form of attitudes, values, norms, behavior, languages, beliefs, rituals that are formed, developed and passed on to members of the organization as organizational personality that distinguishes from other organizations and determines how the group perceives, thinks, and reacts to diverse environments and functions to overcome internal and external adaptation problems.

Robbins and Judge (2016) argued that there are seven main dimensions which as a whole are the essence of the culture of an organization, namely first, innovation and courage to take risks, the extent to which employees are encouraged to be innovative and risk-taking. Second, attention to details; the extent to which employees carry out precision, analysis and attention to small things. Third, result-oriented; the extent to which management more focuses on results than on the techniques and processes used to achieve the results. Fourth, person orientation; the extent to which management decisions consider the effect of these results on people in the organization. Fifth, team orientation; the extent to which work activities in an organization are team-oriented rather than individuals. Sixth, aggressiveness; the extent to which people are aggressive and competitive rather than getting slowly. Seventh, stability; the extent to which organizational activities emphasize maintaining the status quo in comparison to growth.

\section{Job Satisfaction}

Locke (1990) in Khuong and Tien (2013) defines job satisfaction as a statement of a pleasurable or positive emotional state resulting from the appraisal of one's job or job experience. In another part Locke (1990) in Pandey (2012) defines job satisfaction as a positive attitude experienced by an employee in relation to work or work situation. Robbins (2007) defines job satisfaction as a positive feeling about one's job resulting from an evaluation of its characteristic. According to Robbins, people who have a high level of job satisfaction have positive feelings about work, while the dissatisfied people have negative feeling about work.

Armstorng (2012) in Ali, et al. (2013) defines job satisfaction as employees' feelings and attitudes towards their work. Armstrong emphasized that if employees have a plerasurable and positive attitude towards their work, that means there is job satisfaction, but if employees are not happy and negative about work, that means there is dissatisfaction. Glinow and Mcshane (2008) explain that job satisfaction is an evaluation of employees about their work and the context of 


\title{
International Advanced Research Journal in Science, Engineering and Technology
}

\author{
Vol. 5, Issue 10, October 2018
}

their work is the attitude most widely studied. Job satisfaction is an assessment of the perception of job characteristics, work environment, emotional experience at work. Job satisfaction is the attitude of employees regarding various aspects and contexts of work.

Colquitt, et al. (2011) define job satisfaction as an expression of feeling of pleasure caused by an assessment of one's work or work experience. Job satisfaction represents one's feelings and thoughts about their work. Kreitner and Kinicki (2007) define job satisfaction as a response to affective or emotional response to various aspects of their work. Rose (2001) in Funmilola et al. (2013) describes the dimensions of job satisfaction; first, pay (financial compensation). Pay refers to the amount of financial compensation received. Salaries or wages not only help employees to meet basic needs, but also a satisfying tool for higher needs. Second, promotion. Sajuyigbe et al. (2013) in Funmilola et al. (2013) found that many people get satisfaction when they believe that their future prospects are good. If employees have limited career opportunities, their job satisfaction may be reduced. If the organization wants to improve employee performance in the organization, then the organization must provide fair promotion to its employees.

Third, supervision. Brunetto and Far-Wharton (2002) in Funmilola, et al. (2013) concluded that closeness with managers will increase the level of job satisfaction and performance. The productivity and performance of the subordinates can be improved by actions and supervision taken by the management. Sajuyigbe, et al. (2013) in Funmilola, et al. (2013) noted that recognition of success by superiors will lead to job satisfaction. Supervision plays a significant role in job satisfaction and performance. Fourth, work itself. Employees get satisfaction from the fun and challenging work and from work itself to show status. They concluded that work has a significant effect on job satisfaction and performance. In the condition of feasible challenge, most employees will get pleasure and satisfaction. Fifth, working conditions. The good working conditions, such as a clean environment make it easier for employees to complete their work. On the other hand, if the unpleasant work environment, such as hot and noisy environment, will make it difficult for employees to complete their work which results in dissatisfaction. According to Sajuyigbe, et al. (2013) in Funmilola et al. (2013), working conditions may only have an impact on job satisfaction and performance in extreme working conditions, such as too good or too bad.

\section{Performance}

Every human has the potential to act in various forms of activity. The ability to act can be obtained by humans both naturally (endowment) or by learning. Although humans have the potential to behave in certain ways, they are only actualized at certain times. The potential for certain behaviors is called ability, whereas the expression of this potential is known as performance (Mathis and Jackson, 2001). Hasibuan (2005) suggests that performance is a result of work achieved by a person in carrying out tasks that are charged to him based on skills, experience, sincerity, and time.

According to Rivai (2005) the concept of performance is the real behavior displayed by each person as the work performance produced by employees in accordance with their role in the company. Whereas in the opinion of Ilyas (2005) the notion of performance is the appearance, the work of the personnel both the quality, and the quantity of individual appearance and the work group of personnel, the appearance of the work is not limited to personnel who hold functional and structural positions but also to the entire range of personnel within organization. Cash and Fischer (1987) suggested that performance is often referred to as performance or result which is defined by what has been produced by employees individually.

According to Ilyas (2001), a person's performance is influenced by the existence of elements of cooperation, determination, and ability to obey, implement and practice something that is obeyed with full awareness and responsibility. That determination and ability must be proven in the daily attitudes and behavior in carrying out the work. The second element of work performance is the result of the implementation of the work achieved by a person in carrying out the tasks assigned to him. A person's work performance is influenced by skills, ability, experience, excellence, and work environment. The third element is responsibility that is the ability of a person to complete the work that is submitted to him well, on time, and dare to take risks on the decisions made or actions taken. And the fourth is obedience, namely the ability of a person to obey all applicable official regulations, and obey the service orders given by the authorized superiors, and are unable to violate the specified prohibition.

\section{THE RELATIONSHIP BETWEEN THE VARIABLES AND HYPOTHESIS DEVELOPMENT}

Job satisfaction in a company or organization does not come naturally. One of the determining factors of job satisfaction is transformational leadership. Transformational leadership is always present in the midst of employees, giving an example of work commitment, inspiring and motivating employees, and giving fair and decent rewards to employees. Such leadership style will produce satisfaction in work. In this soulful atmosphere, employees will work earnestly, exerting all the effort they have for the advancement of the organization.

In the previous studies, some researchers proved that transformational leadership has an effect on job satisfaction. Cumming, et al. (2009) stated that leadership that only concerns with the output of the employees and does not care about the feelings of the employees will fail to get the best efforts of its employees. The results suggested that transformational leadership must be adopted to improve job satisfaction, selection, and work environment and to avoid 


\title{
International Advanced Research Journal in Science, Engineering and Technology
}

\author{
Vol. 5, Issue 10, October 2018
}

turnover. Miles and Mangold (2002) stated that job satisfaction is facilitated by the performance of leaders and the interaction of effective supervision with the employees. The ability of the leaders to identify and resolve employee conflicts determines employees' perceptions of the performance of their leaders. Positive perceptions of employees on their leaders will generate job satisfaction.

Hussami (2007) concluded that transformational leadership has positive effect on job satisfaction. Hamidifar (2009) conducted a research in Islamic Azad University in Taheran and explored that, among the existing leadership styles, transformational leadership has positive effect on job satisfaction. Employees are more satisfied than in other leadership styles. Voon, et al. (2011) also concluded that transformational leadership has a positive relationship with job satisfaction. Ali, et al. (2013) also proved that there is a strong relationship between transformational leadership and job satisfaction.

In addition, in previous studies conducted by Rais, et al. (2010); Abouraia, et al. (2017), Wang, et al. (2011); Paracha, et al. (2012); and Bushara, et al. (2011), it was stated that transformational leadership style has a positive effect on job satisfaction. Some of the studies wanted to prove that transformational leadership has a positive effect in creating job satisfaction of employees in a company or organization. From the description above, the researcher have made some hypotheses, as follows:

\section{H1: Transformational leadership will improve job satisfaction}

In general, organizational culture can accommodate some of the diversity found within an organization and can provide comfort and satisfaction in working for the employees. The appropriate type of organizational culture will have an effect on the comfort and satisfaction in working for employees as the members of a company or organization.

Organizational culture can help employees at work, because it will create an extraordinary level of motivation for employees to provide their best ability in utilizing the opportunities provided by the organization. The shared values make employees get some comfort at work, have commitment and loyalty to work for the company. Comfort, loyalty, and high commitment are obtained from their soul condition in which they are satisfied with the organizational culture adopted by a company.

In previous studies conducted by Nahas, et al. (2012), Habib, et al. (2014), Lund (2003), Davoodalmousavi (2013), it was suggested that organizational culture has an effect on job satisfaction, means that organizational culture has positive and unidirectional effect on job satisfaction. From the description above, the researcher proposed the following hypothesis:

\section{H2: The strong organizational culture will improve job satisfaction}

Leadership is an effort to influence many people through the communication process to achieve organizational goals, which is expected to lead to positive changes in the form of strengths that can dynamically move, encourage, and motivate organizational members in order to achieve goals in accordance with the corridors set by the management. The appropriate leadership style can motivate employees to improve their performance. Improvement in performance will result in improvement in employee performance in particular, while simultaneously improving the performance of the company.

Transformational leadership is concerned with improving followers' performance, and developing followers to reach their maximum potential (Bas \& Avolio, 1999). People who have transformational leadership style often have strong internal values and principles. They are effective in motivating followers to act in ways that support greater interests than their own interests (Kuhnert, 1994). An organization or company that has a transformational characteristics can certainly inspire its employees to achieve maximum performance. Through such figure, the organizational culture and job satisfaction of employees will be built which will lead to improvement in employee performance.

In addition, in previous studies conducted by Paracha, et al. (2012), Wang, et al. (2011), Nemanich and Keller (2007), it was stated that transformational leadership can encourage and improve employee performance. Based on the description above, the researcher made a conclusion by proposing the following hypothesis:

\section{H3: Transformational Leadership can improve employee performance.}

Organizational culture is conceptualized as shared beliefs and values in an organization that help shaping the behavior patterns of the employees (Kotter and Heskett, 1992). Gordon and Cummins (1979) defined organizational culture as an encouragement that recognizes the efforts and contributions of organizational members and provides a holistic understanding of what and how it is achieved, how goals are interrelated, and how each employee can achieve goals. These thoughts emphasize that organizational culture can be a means of maintaining and directing in order to achieve the goals of the organization or company. Achieving the goals of the company or organization requires the employees to have high level of performance. Therefore, there is a need of an appropriate organizational culture in order to encourage good performance among employees.

Strong organizational culture supports adaptation and develops employee performance in the organization and motivates employees towards shared goals and objectives; and finally form and direct employee behavior in a particular direction to be at the top of operational and functional strategies (Daft, 2010). This thought emphasizes that organizational culture is positively correlated for the development of employee performance to achieve company goals. 


\title{
International Advanced Research Journal in Science, Engineering and Technology
}

\author{
Vol. 5, Issue 10, October 2018
}

In previous studies conducted by Udin, et al. (2013), Jacobs, et al. (2012), Shahzad, et al. (2013), it was stated that organizational culture has a positive effect on employee performance. From the descriptions above, the researcher proposed the following hypothesis:

\section{H4: The strong organizational culture will improve employee performance.}

In general, the assessment of job satisfaction in an organization or company is an accumulation of feelings or attitudes of employees towards their work. The feelings and attitudes of employees are closely related to the work environment, type of work, compensation, relationships between colleagues, social relations at work, and so on. Thus, it can be said that job satisfaction is a condition where the fulfillment of some of the desires and needs of employees in their work.

An employee who feels satisfied with his work, work environment, and appropriate compensation for his workload will have high enthusiasm at work. High morale will encourage employees to improve their work performance so as to encourage overall employee performance. Some previous studies proved that job satisfaction can encourage maximum performance achievement. Nanda and Brown (1977) in their research concluded that the level of job satisfaction and motivation will affect employee productivity. Meanwhile, the low level of satisfaction has a negative effect on commitment, achievement of company goals, and performance of the employees (Meyer, 1999).

In addition, in previous studies conducted by Khan, et al. (2012), Wright, et al. (2000), Funmilola, et al. (2013) it was stated that job satisfaction has a positive effect on employee performance. Employees who are satisfied with their work will give all their ability to achieve the visions and goals of the company. Based on the description above, the researcher made a conclusion by proposing the following hypothesis:

H5: The high level of job satisfaction will improve employee performance.

\section{RESEARCH METHODOLOGY}

Research Design: This study used causality design to determine the relationship between two or more variables. Causality design research is used to analyze the relationship between one variable and other variables (Umar, 2009).

Measurement: According to Sugiono (2012), variable is an attribute or property or value of another person, object, or activity that has a certain variation set by the researcher to study and make conclusions. Variable is the characteristic that will be observed from the observed unit and is an introduction or attribute of a group of objects. There were four variables measured in this study, namely transformational leadership, organizational culture, job satisfaction, and performance. The measurement of transformational leadership variable used four dimensions based on Avolio, Bass, and Jung (1997) namely idealized influence, inspirational motivation, intellectual stimulation and individualized consideration.

The measurement of organizational culture used seven (7) indicators based on Robbins and Judge (2008), namely innovation and risk taking, attention to details, result orientation, person orientation, team orientation, aggressiveness, and stability. Furthermore, the measurement of job satisfaction used dimensions based on Rose (2001) in Funmilola, et al. (2013), namely pay, promotion, supervision, work itself, and working conditions, while the measurement of performance used the dimensions based on Ilyas (2001), namely achievement, responsibility, obedience, honesty, cooperation, and initiative.

Data Collection and Sample: This study used Likert scale, which is a measurement technique in which the subjects are asked to indicate their level of agreement or disagreement towards each statement (Noor, 2011). Likert scale is used for measuring attitudes, opinions, and perceptions of a person or group of people about certain social phenomena (Sugiyono, 2010). In a Likert scale, the method used is the five alternative options. The object of the study was the teachers at several Catholic schools in West Jakarta. The data were collected by distributing questionnaires to teachers. The data were analyzed using Structural Equation Modeling (SEM) method. According to Hair, et al. (2008), the determination of the number of samples for SEM depends on the number of indicators multiplied by five. The number of respondents needed in this study was 205 respondents.

\section{RESULTS AND DISCUSSION}

The sudy obtained th value of Chi Square/Degree of Freedom $=1,71$, RMSEA $=00,59$ (good fit), ECVI $=2,43$ (good fit) around the ECVISaturated $=2,71$, AIC Model $=495,21$ compared to AIC Saturated $=552,00$ and AIC Independence $=31108,58$. AIC Model is slightly lower than AIC Saturated and much lower than AIC independence, so that the lower value indicates the good fit. CAIC Model $=823,75$ is lower than CAIC Saturated $=1745,15$, and much lower than CAIC Independence $=31208,01$, so that the lower value indicates the good fit. Nomed Fix Index $(\mathrm{NFI})=0,99(>0,90)$ shows good fit. Critical $\mathrm{N}(\mathrm{CN})=145,09(<200)$, so that the model indicates that the sample size is marginal fit. Goodness of Fit Index $(\mathrm{GFI})=0,87$, The ideal value $>0,90$ indicates marginal fit. Furthermore, this study produced the T-value diagram as shown in Figure 1. 


\section{International Advanced Research Journal in Science, Engineering and Technology}

Vol. 5, Issue 10, October 2018

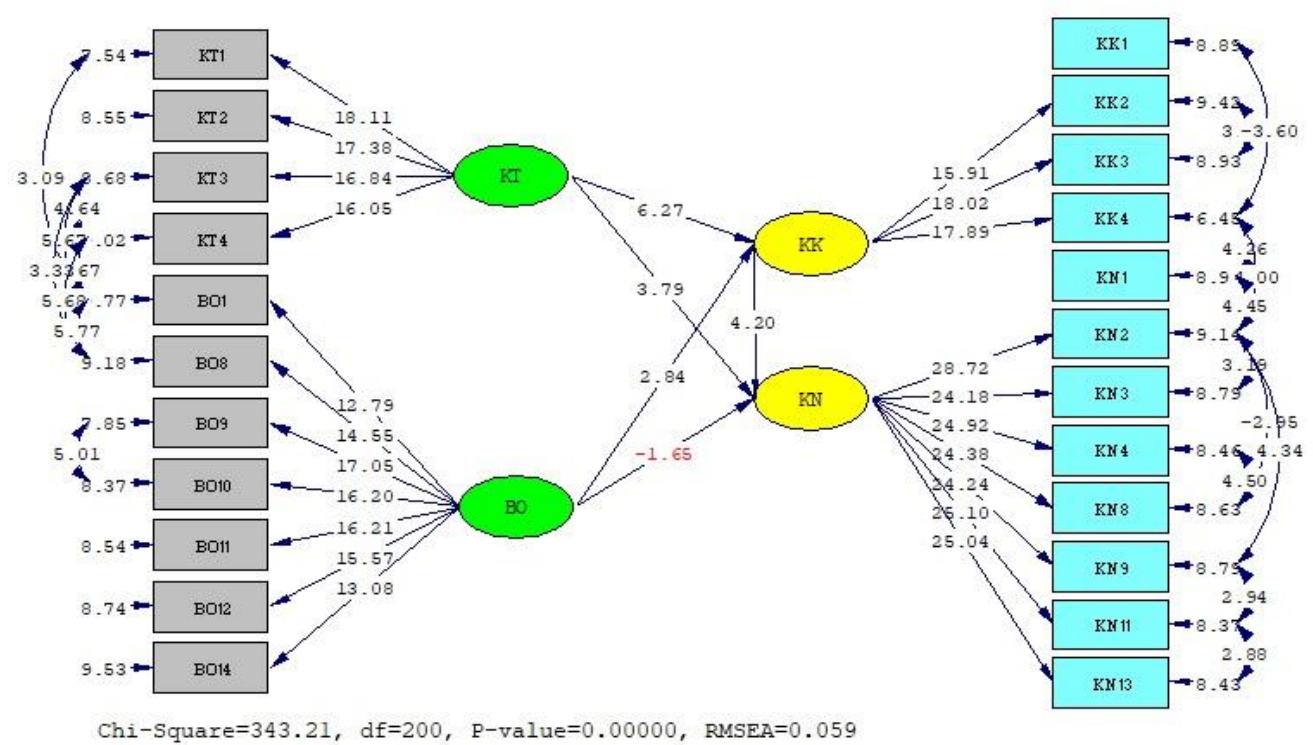

Figure 1. Path Diagram T-Value

In this study, there are 5 hypotheses tested and based on the results of test. The results showed that there are 4 hypotheses supported by the data and 1 hypothesis is not supported by the data.

Table 1. The Hypothesis Test of Research Model

\begin{tabular}{|l|l|l|l|}
\hline Hypothesis & Hypothesis Statement & T-Value & Information \\
\hline $\mathrm{H}_{1}$ & $\begin{array}{l}\text { Transformational leadership will } \\
\text { improve job satisfaction }\end{array}$ & 6,27 & $\begin{array}{l}\text { The data supports the } \\
\text { hypothesis }\end{array}$ \\
\hline $\mathrm{H}_{2}$ & $\begin{array}{l}\text { The strong organizational culture } \\
\text { will improve job satisfaction }\end{array}$ & 2,84 & $\begin{array}{l}\text { The data supports the } \\
\text { hypothesis }\end{array}$ \\
\hline $\mathrm{H}_{3}$ & $\begin{array}{l}\text { Transformational leadership can } \\
\text { improve employee performance. }\end{array}$ & 3,79 & $\begin{array}{l}\text { The data supports the } \\
\text { hypothesis }\end{array}$ \\
\hline $\mathrm{H}_{4}$ & $\begin{array}{l}\text { The strong organizational culture } \\
\text { will improve employee performance }\end{array}$ & $-1,65$ & $\begin{array}{l}\text { The data does not } \\
\text { support the hypothesis }\end{array}$ \\
\hline $\mathrm{H}_{5}$ & $\begin{array}{l}\text { The high level of job satisfaction will } \\
\text { improve employee performance. }\end{array}$ & 4,20 & $\begin{array}{l}\text { The data supports the } \\
\text { hypothesis }\end{array}$ \\
\hline
\end{tabular}

In the results of the test of the first hypothesis $\left(\mathrm{H}_{1}\right)$, it was found that the results of the analysis supported $\mathrm{H} 1$ hypothesis that transformational leadership will improve job satisfaction with a T-Value of 6,27 . It means that transformational leadership has a positive or significant effect on job satisfaction of the teachers. Teachers experience that the school management and foundations are able to give motivation and inspiration, provide fair and objective assessments, see the potential of subordinates and support employees to get achievement. These factors create satisfaction in the teachers. The results of this study are in line with previous studies conducted by Raiz, et al. (2010); Abouraia, et al. (2017), and Wang, et al. (2011) which stated that transformational leadership has a positive effect on job satisfaction. Similarly, Paracha, et al. (2012) and Bushara, et al. (2011), in their study, concluded that transformational leadership has a positive effect on job satisfaction.

In the results of the test of the second hypothesis (H2), it was found that a strong organizational culture will improve job satisfaction with a T-Value of 2,84. The results indicated that a strong organizational culture has a positive and significant effect on job satisfaction of the teachers in several Catholic school foundations in West Jakarta. The values of organizational culture, such as togetherness, cooperation, responsibility at work, freedom of expression are truly perceived by the teachers. These values create satisfaction at work. The stronger the organizational culture in the Catholic school foundations in West Jakarta, the higher the job satisfaction perceived by the teachers. The results of this study confirmed the results of previous studies conducted by Nahas, et al. (2012), Habib, et al. (2014), Lund (2003), and Davoodalmousavi (2013). The conclusion based on the results is that a strong organizational culture will improve job satisfaction. Thus, the stronger the organizational culture of a company, the higher the level of job satisfaction of the employees. 


\title{
International Advanced Research Journal in Science, Engineering and Technology
}

\author{
Vol. 5, Issue 10, October 2018
}

In the results of the test of the third hypothesis $(\mathrm{H} 3)$, it was found that transformational leadership can improve employee performance with a T-Value of 3,79 . The results indicated that transformational leadership has a positive and significant effect on the performance of teachers. Teachers perceive that school leader or foundation always provide motivation, exemplary life, as well as inspiration to the teachers at work. The effect on the performance of the teachers is that they can work according to their skills, can solve problems properly, are motivated to provide constructive ideas for the advancement of the school, can build good relations with the superiors, and able to work together in teams. The results of this study supported the previous studies conducted by Paracha, et al. (2012), Wang, et al. (2011), Nemanich and Keller (2007). The conclusion of the studies is that transformational leadership can encourage and improve employee performance.

In the results of the test of the fourth hypothesis (H4), it was found that a strong organizational culture does not have any effect on the improvement on employee/teacher performance with a T-Value of $-1,65$, as the data of study does not support the hypothesis. The results indicated that a strong organizational culture does not have a direct effect on the performance of the teachers in some Catholic school foundations in West Jakarta. From the results of interviews with several school coordinators and principals, they explained that when school management and foundation emphasize the importance of teamwork in carrying out certain tasks, some teachers are getting complacent, not creative, depending on each other, lacking personal responsibility, and not maximal at work. Dependence on each other is so high because it is not proactive and participatory in completing the work. Thus, the teamwork culture in certain context does not have a positive effect on improving the performance of teachers in Catholic schools in West Jakarta. In the results of the test of the fifth hypothesis (H5), it was found that the results of analysis supported the hypothesis with a T-Value of 4,20 in which the data supported the hypothesis. It means that the high level of job satisfaction has a positive effect on improving the performance of teachers in several Catholic school foundations in West Jakarta. Most teachers agree that they get wages as expected and suited to their workload. They also get the opportunity to be promoted to the higher position. The schools where they work have clear future prospects and a good career path. The results of this study confirmed several previous studies conducted by Khan, et al. (2012), Wright, et al. (2000), and Funmilola, et al. (2013). The conclusion of the studies stated that job satisfaction has a positive effect on employee performance. Employees who are satisfied with their work will give all their ability to achieve the visions and goals of the company.

Based on the results of the coefficient difference on the research model, transformational leadership has a direct effect on job satisfaction of the teachers with a t-value of $6,27(>1,96)$, transformational leadership has a direct effect on the performance of teachers with a t-value of $3,79(>1,96)$, organizational culture has a direct effect on job satisfaction of the teachers with a tvalue of 2,84 (> 1,69), organizational culture does not have a direct effect on teacher performance with a t-value of $-1,65(<$ $1,69)$ and job satisfaction of the teachers has a direct effect on teacher performance with a t-value of 4,20 $(>1,69)$.

Thus, it can be concluded that job satisfaction of the teachers is a partial mediation between transformational leadership on performance and, at the same time, job satisfaction is also a full mediation because organizational culture does not have direct effect on teacher performance. Some analyses can be done when job satisfaction of the teachers becomes a partial mediation between transformational leadership and teacher performance; first, leaders who always give motivation and enthusiasm to teachers to create can encourage the teachers to provide constructive ideas for organizational improvement. These positive ideas will be easily implemented in the work as teachers if supported by a leadership spirit that is able to support teachers to excel. Strong moral support from leaders will improve teacher performance.

Second, leaders who always explain the company's visions and missions can create confidence in the teachers that the company or school has good future prospects. The clarity of the school's visions and missions will further encourage teachers to exert all their efforts to realize the visions and missions. The psychological condition that is full of satisfaction will then be a trigger for improving the performance of teachers.

In addition to being a partial mediation, job satisfaction also fully mediates the organizational culture on teacher performance. The results showed that a strong organizational culture does not improve the performance of teachers. Organizational culture that emphasizes the importance of giving rewards or awards to outstanding teachers will have a positive psychological effect in the teachers. The psychological effect in the form of pride and happiness. This pride then becomes a motivator to work better and more optimal. Every job that is done well and maximally will certainly give good results. Thus, the teacher performance can be improved.

\section{CONCLUSIONS AND SUGGESTIONS}

\section{Conclusions}

Based on the results, it can be concluded that; first, transformational leadership can improve job satisfaction of the teachers (the data supports the first hypothesis). The stronger the transformational leadership in an institution will be able to increase the level of job satisfaction of the teachers. Some implications that need to be considered by school management and foundations to strengthen transformational leadership, namely; preparing a pocket book about the visions and missions of the foundation, always talking about the visions and missions of the foundation in any occassion of a joint meeting, displaying the visions and missions of the foundation in central and strategic places in 


\title{
International Advanced Research Journal in Science, Engineering and Technology
}

\author{
Vol. 5, Issue 10, October 2018
}

schools, providing opportunities for teachers to make certain projects based on their skills and competencies, making clear and measurable performance assessment standards, organizing Outbound activities and Focus Group Discussion. The second conclusion of this study is that a strong organizational culture can improve job satisfaction (the second hypothesis is supported by data). The stronger the organizational culture, the higher the job satisfaction of teachers who work in the organizations or schools. In order to strengthen the values of organizational culture, several activities that need to be done are requiring the teachers to always give greetings or shake hands every day before starting teaching and learning activities in schools, forming social gathering groups, collecting solidarity funds for any celebration or death, forming FGD/group discussion, giving award certificates to the outstanding teachers, making family gathering activities once a year, making Ret-Ret (religous) activities for teachers once a year, making Masses (religious services) at the opening of the school year and at the end of the school year, organizing Fun Day activities once a month with evaluation, sharing, games, and quizzes with prizes.

The third conclusion is that transformational leadership can improve teacher performance (the third hypothesis is supported by data). The next conclusion is that a strong organizational culture does not have direct effect on teacher performance (this fourth hypothesis is not supported by data). The last conclusion is that the high level of job satisfaction of the teachers can improve performance (the fourth hypothesis is supported by data). Teachers need to get satisfaction at work, so that with such satisfaction, they can be more motivated to improve their performance. Strategic things that need to be done by the school management and the foundation are to make an evaluation of teacher salaries based on years of service, provide promotions to teachers who excel, build some supporting facilities and infrastructures, provide duties and responsibilities to teachers in accordance with their skills and expertise, and provide appropriate compensation according to their workload.

\section{Limitations of the Research}

There were some limitations in this study that can be considered for further research. This study used questionnaire as a measuring tool because of the need to save time and energy. However, the questionnaire has limitations, such as ambiguity in formulating statements and responses from respondents. There is a possibility that the respondents did not fill in properly because of their business or just fill in based on the expected ideal, not the actual conditions. This can cause the measurement used does not describe the variables significantly. In addition, the limited number of samples, 205 respondents, and four variables caused the research process could not explore more about other factors that have an effect on the performance of teachers.

\section{Suggestions}

Based on the findings of the results in this study, there are several things that need attention for further research, namely; first, research can still be done in the same organization by adding other variables that have an effect on performance; second, the research population can be expanded or reproduced so that it can get more accurate and representative results; third, data collection procedures are not only through questionnaires but also other ways, such as interviews.

\section{REFERENCES}

[1]. Abdul Hakim. (2014). Organizational culture and job satisfaction in bank: perceptions and reactions of employees. Global Disclosure of Economics and Business. Volume 4, 167-180.

[2]. Adnan Riaz., Mubarak Hussain Haider. (2010). Role of transformational and transactional leadership on job satisfaction and career satisfaction. Journal of Business and Economic Horizons. Volume 1, 29-38.

[3]. Ahmad Sobirin. (2002). Budaya organisasi: pengertian, makna dan aplikasinya dalam kehidupan organisasi. UPP STIM YKPN.

[4]. Ahmad Sobirin. (2007). Budaya organisasi: pengertian, makna dan aplikasinya dalam kehidupan organisasi. Yogyakarta : IBPP STIM YKPN.

[5]. Al-Husammi, M. (2008). A Study of nurse's job satisfaction: the relationship to organizational commitment, perceived organizational support, transactional leadership, transformational leadership, and level of education. European Journal of Scientific Research, 22 (2), $286-295$.

[6]. Alamdar Hussain Khan., Muhammad Musarrat Nawaz., Muhammad Akem., dan Wasim Hammed. (2012). Impact of job satisfaction on employee performance: an empirical study of autonomus medical institutions of Pakistan. African Journal of Business Management. Vol.6 (7), $2697-2705$.

[7]. Ali Yassin Sheikh Ali., Mohamed Abdiazis Sidow., Hamdi Salad Guleid. (2013). Leadership styles and job satisfaction: empirical evidence from Mogadishu Universities. European Journal of Management Sciences and Economics. Vol.1, 1-10.

[8]. Amstrong, Michael. (2006). Human Resourches management Practise. London: Kopan page.

[9]. Avolio, B.J., Bass, B,M., \& Jung, D.I. 1997. Replicated confirmatory factor analyses of the multi factor leadership questionnaire. Binghamton, NY: Center for Leadership Studies, Binghamton University.

[10]. Bass, B.M. (1985). Leadership and performance beyond expectations. New York: The Free Press.

[11]. Colquitt, Jason A., Jeffery A. Lepine., and Michell J.Wesson. (2011). Organizational behaviour. New York: McGraw-Hill International.

[12]. Cummings, G.G., Tara MacGregor., Mandy Davey., How Lee., Wong, Carol.A., Eliza Lo., Melanie Muise., Erin Stafford. (2009). Leadership styles and outcome patterns for the nursing workforce and work enviroment: a systematic review. International Journal of Nursing Studies , 23.

[13]. Daft, Richard L. (2010). Era baru manajemen. Edisi kesembilan. Buku 2. Jakarta: Salemba Empat.

[14]. Daulatram, B. Lund. (2003). Organizational culture and job satisfaction. Journal of Business and Industrial Marketing. Vol.18, No.3, 219-236.

[15]. Davoodalmousavi, S.M. (2013). The Correlation between organizational culture and job satisfaction of employees in biotechnology production companies. European Journal of Experimental Biology, 3 (5), 389-399.

[16]. Fatima Bushara., Ahmad Usman., Asvir Naved. (2011). Effect of transformational leadership on employees' job satisfaction and organizational commitment in banking sector of Lahore (Pakistan). International Journal of Business and Social Science. Vol.2, No.18, 261-267. 


\title{
International Advanced Research Journal in Science, Engineering and Technology
}

\author{
Vol. 5, Issue 10, October 2018
}

[17]. Funmilola, O.F., Sola, K.T., Olusola, A.G. (2013). Impact of job satisfaction dimension on job performance in a small and medium enterprise in Ibadan, South Western, Nigeria. Interdiciplinary Journal of Contemporary Research in Business. Vol.4, No.11.

[18]. Gang Wang., In Sue Oh., Courtright, S.H., Colbert, A.E. (2011). Transformational leadership and performance across criteria and levels: a meta-analytic review of 25 years of research. Group and Organization Management. 36 (2), 223-270.

[19]. Habib, S., Aslam, S., Hussain, A., Yasmen, S., Ibrahim, M., (2014). The impact of organizational culture on job satisfaction, employees commitment and turnover intention. Advance in Economic and Business. Vol 2 (6). Pp. 215-222.

[20]. Hair, J.F., Black, W.C., Babin, B.J., Anderson, R.E., and Tatham, R.L. (2008). Multivariate data analysis. 6th ed. New Jersey: Pearson Prentice Hall.

[21]. Hamidifar, F. (2009). A Study of the relationship between leadership styles and employee job satisfaction at Islamic Azad University branches in Tehran, Iran. AU-GSB e-Journal, 1-13.

[22]. Hasibuan. (2005). Manajemen sumber daya manusia. Edisi revisi. Jakarta : PT Bumi Aksara.

[23]. Ilyas, Yaslis. (2005). Kinerja teori, penilaian dan penelitian. Jakarta : Pusat Kajian Ilmu ekonomi Kesehatan Fakultas Kesehatan Masyarakat Universitas Indonesia, Jakarta.

[24]. Jacobs, R., Mannion, R., Davies, Huw T.O., Harisson, S., Kouteh, F., Walsche, K., (2013). The relationship between organizational culture and performance in acute hospitals. Social Science and Medicine. Vol 76, pp. 115-125.

[25]. Khuong, M.N., dan Tiem, B.D. (2013). Factors influencing employee loyalty directly and indirectly through job satisfaction - a study of banking sector in Ho Chi Minh City. International Journal of Current Research and Academic Review. Vol.1, No.4

[26]. Kreitner, R., and Kinicki, A. (2005). Perilaku organisasi. Terjemahan. Jakarta: Salemba Empat.

[27]. --------------- (2007). Organizational behaviour. Seventh edition, McGraw-Hill International.

[28]. Mathis dan Jackson. (2001). Manajemen sumber daya manusia. Buku kedua. Jakarta: Salemba Empat.

[29]. Mcshane., Steven L., Von Glinow., Mary Ann. (2010). Organizational behaviour (fourth Edition). McGraw Hill-International. USA

[30]. Maslowski, R. (2001). School culture and school performance. Disertasi Twente University Press Netherlands, diakses dari www.tup.utwente.nl / nk / catologue / educational /school-culture, 22 Mei 2012.

[31]. Mahmoud Kamal Abouraia., Saad Mohammed Othman. (2017). Transformational leadership, job satisfaction, organizational commitment, and turnover intentions: the direct effects among bank representatives. American Journal of Industrial and Business Managements. Vol.7, 404-423.

[32]. M. Umer Paracha., Adnan Qamar., Anam Mirza., Inam-Ul-Hassan \& Hamid Wagas. (2012). Impact of leadership style (transformational \& transactional leadership) on employee performance \& mediating role of job satisfaction-study of private school (educator) in Pakistan. Global Journal of Management and Business Research. Vol. 12, 1-9.

[33]. M.L, Voon., M.C, Lo., Ngui., N.B, Ayob. (2011). The influence of leadership styles on employees' job satisfaction in public sector organizations in Malasyia. International Journal of Business Management and Social Sciences. Vol. 2, No.1, 24-32.

[34]. Mohammad Jasim Uddin., Rumana Huq Luva., Saad Md.Maroof Hossian. (2013). Impact of organizational culture on employee performance and productivity: a case study of telecommunication sector in Bangladesh. International Journal of Business and Management. Vol.8, No.2, 63-77.

[35]. Nemanich, Louise A., and Keller, Robert T. (2007). Transformational leadership in acquisition: a field study of employees. Leadership Quarterly. Vol.18, 49-68.

[36]. Noor, Juliansyah. (2011). Metodologi penelitian. Jakarta: Prenada Media Group.

[37]. Pandey., Chetna., and Rajni Kahre. (2012). Impact of job satisfaction and organizational commitment on employee loyalty. International Journal of Science and Interdisciplinary Research. Vol.1

[38]. Rivai, V. (2005). Manajemen sumber daya manusia dari teori ke praktek. Jakarta: Raja Grafindo Persada.

[39]. Robbins, Stephen P. (2006). Perilaku organisasi. Edisi kesepuluh. Jakarta: Index Kelompok Gramedia.

[40]. Robbins dan Judge. (2016). Perilaku organisasi. Edisi keduabelas. Jakarta: Salemba Empat.

[41]. Rowley, Chris., dan Jackson, Keith. (2012). Manajemen sumber daya manusia: The key concepts. (Elviyola Pawan, penerjemah). Cetakan kedua. Jakarta: Raja Grafindo Persada.

[42]. Ruyatnasih., Anwar Musadad., Beni Hasyim. (2013). Pengaruh gaya kepemimpinan terhadap kinerja karyawan. Jurnal Manajemen. Vol. 10.

[43]. Schein, Edgar H. (1999). The corporate culture survival guide: sense and non sense about culture change. San Francisco, CA: Jossey-Bass Publishers.

[44]. Siagian, S.P. (1995). Teori motivasi dan aplikasinya. Jakarta: Rineka Cipta.

[45]. Soetopo, Hendyat. (2010). Perilaku organisasi. Jakarta: Remaja Rosdakarya.

[46]. Simamora, Henry. (1997). Manajemen sumber daya manusia. STIE YKPN, Yogyakarta.

[47]. Schuler, S dan Susan.E, Jackson. (1997). Manajemen sumber daya manusia (menghadapi abad ke-21). Jakarta : Gelora Aksara.

[48]. Shahzad, Fakhar., Iqbal Zahid., dan Gulzar Muhammad. (2013). Impact of organizational culture and employees' job performance: an empirical study of software houses in Pakistan. Journal of Business Studies Querterly. Vol.5, Number.2, 56-64.

[49]. Sugiono. (2012). Metode penelitian. Bandung: Alfabeta

[50]. Tawfik El, Nahas., Eman Mohamed Abd-El-Salam., Ayman Yehia Shawsky. (2012). The impact of leadership behaviour and organizational culture on job satisfaction and its relationship among organizational commitment and turnover intentions: a case study on Egyptian company. The Business and management Review. Vol. 3, Number.1, 66-85.

[51]. Umar, Husein. (2009). Metode Penelitian untuk Skripsi dan Tesis Bisnis. Edisi II. PT Raja Grafindo Persada. Jakarta.

[52]. Yukl, Garry. (2006). Leadership in organizations. New Jersey: Pearson Education, Inc., Upper Saddle River. 